\title{
Histo-morphological study of a giant Meckel's diverticulum with gastric type of mucosa
}

\author{
NAYAK, B. S. ${ }^{1 *}$, SHETTY, P. ${ }^{1}$, SIRASANAGANDLA, S. R. ${ }^{2}$, KUMAR, N. ${ }^{1}$ and \\ AITHAL, A. P. ${ }^{1}$ \\ ${ }^{1}$ Melaka Manipal Medical College, Manipal University, Madhav Nagar, Manipal, Karnataka, 576104, India \\ ${ }^{2}$ Department of Human and Clinical Anatomy, College of Medicine and Health Sciences, \\ Sultan Qaboos University, Muscat-123, Oman \\ *E-mail: nayaksathish@gmail.com
}

\begin{abstract}
Introduction: Meckel's diverticulum or ileal diverticulum is one of the common congenital anomalies of the digestive system. It may not cause any problems in many, but may form serious life threatening complications in a few. Materials and Methods: We conducted a histo-morphological study of a giant Meckel's diverticulum found during cadaveric dissections of a South Indian adult male cadaver. The diverticulum was $7.5 \mathrm{~cm}$ long and had a circumference of $1.5 \mathrm{~cm}$. Results: Gross anatomical and histological observations revealed healthy nature of the diverticulum without any inflammation. However, the mucosa had gastric type of glands with plenty of parietal cells. This incidence of Meckel's diverticulum was noted in only one cadaver among more than 100 cadavers dissected in the past twenty years. Conclusion: Knowledge of its morphological features may be very useful to surgeons, radiologists and gastroenterologists. We discuss the clinical importance of the diverticulum and review the relevant literature in this manuscript.
\end{abstract}

Keywords: Meckel's diverticulum, vitelline duct, ileal diverticulum, intestine.

\section{Introduction}

Meckel's diverticulum or ileal diverticulum is one of the most common congenital anomalies of digestive system. It was reported first in 1809 (MECKEL, 1809). It is a remnant of the vitello-intestinal duct (YAHCHOUCHY, MARANO, ETIENNE et al., 2001; ELSAYES, MENIAS, HARVIN et al., 2007). On an average, it is about 2 inches long, attached to the anti-mesenteric border of the ileum and is situated 2 feet away from the ileocecal junction. It usually contains all the four layers of gastrointestinal tract namely, mucosa, submucosa, muscularis externa and serosa. It occurs in 2-4\% of individuals (CHEN, LEE, YEUNG et al., 2014). Though the diverticulum may go unnoticed throughout life, it may be the cause of surgical emergency in some. It may be freely hanging from the anti-mesenteric border of ileum, may be attached to the umbilicus through a fibrous cord or may form a fecal fistula at the umbilicus. It may result in intestinal obstruction in some (KIM, CHA, LEE et al., 2008) and may have heterotrophic gastric mucosa or pancreatic tissue in others (KILIUS, SAMALAVICIUS, DANYS et al., 2015). It may get infected, ulcerated and perforate, draining the contents into the abdominal cavity. It may even get herniated into the inguinal canal (HORKOFF, SMYTH, and HUNTER, 2014). Intussusception is another complication of Meckel's diverticulum (AMIN, SIDDIQUI and MAHMOOD, 2008). Its infection may mimic symptoms of appendicitis (LAMBROPOULOS, PAPAGEORGIOU, KEPERTIS et al., 2015). We encountered an unusual Meckel's diverticulum during our dissection classes. We did a histo-morphological study of the same and the aim of the study was to know the gross and histological features of the diverticulum. We also review the relevant literature and compare and contrast our findings with the earlier reports available in the literature.

\section{Materials and Methods}

During our dissection classes for medical undergraduates, we observed an unusual Meckel's diverticulum in an adult male cadaver aged approximately 70 years. This diverticulum was found in our dissection hall for the first time in 20 years after dissection of about 100 cadavers (about 90 males and 10 females). We measured the length and diameter of the diverticulum and opened its lumen to study the interior. Photographs were taken before and after studying the internal features. A small piece of the diverticulum was then processed for hematoxylin and eosin staining procedure using standard staining procedures. The small piece obtained was dehydrated, embedded in paraffin wax and subjected to section cutting using a Minot Rotary microtome. 6 micron sections were mounted on glass slides, deparaffinised, rehydrated and stained with hematoxylin and eosin stains. The sections were dehydrated and mounted with Canada balsam. The microscopic features of the sections were studied carefully and the features were noted down. Photomicrographs were obtained at $4 \mathrm{x}$ and $40 \mathrm{x}$ magnifications.

\section{Results}

The Meckel's diverticulum was $7.5 \mathrm{~cm}$ long and had a circumference of $1.5 \mathrm{~cm}$. It was situated $40 \mathrm{~cm}$ away from ileocecal junction and was attached to the antimesenteric border of the ileum. Its tip was free and it had no fibrous or peritoneal attachments (Figure 1). The lumen was as broad as that of the ileum and had fecal matter. The lumen showed only one transverse mucosal fold (Figure 2). However, the part of ileum to which the diverticulum was attached, had many mucosal folds. The wall of the diverticulum was slightly thinner than the wall of the ileum due to the lack of mucosal folds. 
The diverticulum looked healthy, without any inflammation, ulceration or perforations.

The stained sections showed all four layers of alimentary tract namely mucosa, submucosa, muscularis externa and serosa (Figure 3 ). The mucosa had short villi. The lining epithelium was made up of low columnar cells with some goblet cells. The attractive feature of the lamina propria was that it contained tubular "gastric type" of glands with plenty of parietal cells (Figure 4). The submucosa, muscularis externa and serosa had no special features. There was no evidence of any inflammation.

\section{Discussion}

Meckel's diverticulum, like appendix is an unpredictable part of gastrointestinal system. It varies greatly in its size, morphology and clinical behavior. On an average, $2-4 \%$ individuals possess Meckel's diverticulum (CHEN, LEE, YEUNG et al., 2014) and only a few of them face complications related to it. Sancar, Demirci, Sayan et al. (2015) have recently published their ten year experience with Meckel's diverticulum. According to their study, the diverticulum was found in $1.6 \%$ of boys



Figure 1. Photograph of the Meckel's diverticulum observed during dissection classes.

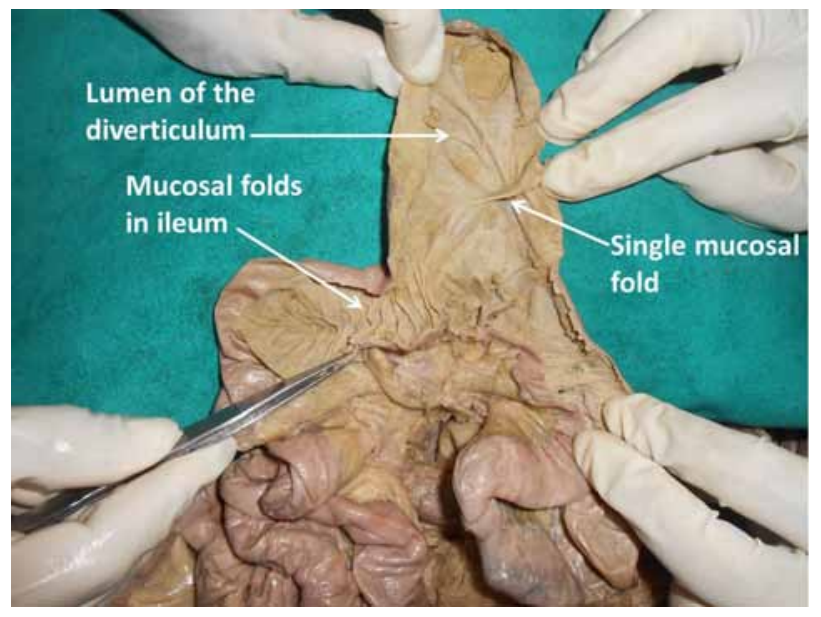

Figure 2. Photograph of lumen of ileum and Meckel's diverticulum. Only one mucosal fold can be seen in the Meckel's diverticulum. and the incidence was three times lower in girls. Since we observed only one case of Meckel's diverticulum over the past twenty years in the South Indian cadavers, the prevalence is low compared to other studies. We could not get reports on statistics of prevalence of the diverticulum in South Indians.

Though, on an average, the diverticulum measures 2 inches, rarely there exist giant diverticula of varying dimensions. Akbulut and Yagmur (2014) have reported the occurrence of a giant Meckel's diverticulum which measured $80 \mathrm{~mm}$. But their case was a Meckel's diverticulitis without gastric or pancreatic metaplasia. The size of the diverticulum observed by us was $75 \mathrm{~mm}$ which is very close to this in spite of having no inflammation or any pathology.

Meckel's diverticulum is a congenital anomaly of the gastrointestinal tract. It occurs due to the failure in the obliteration of the vitello-intestinal duct or omphalomesenteric duct in the $7^{\text {th }}$ week of gestation. Usually the diverticulum appears as a single tube with almost same diameter as that of the ileum. However, five cases of double Meckel's diverticulum have been reported so far (EMRE, AKBULUT, YILMAZ et al., 2013).

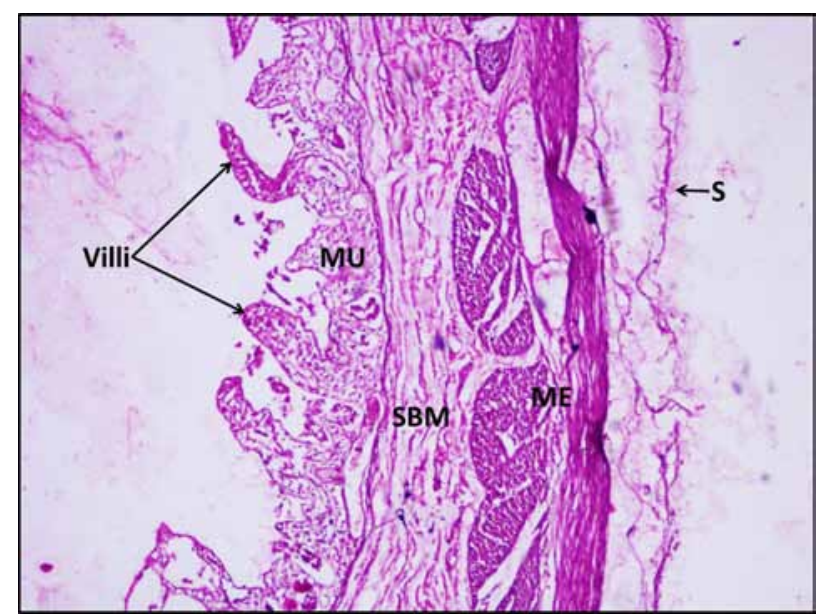

Figure 3. Photomicrograph of the section of Meckel's diverticulum, stained with Hematoxylin and Eosin. We can see the short villi. Mucosa (MU) had gastric type of glands. Submucosa (SBM), muscularis externa (ME) and serosa (S) are also seen. (4x magnification).

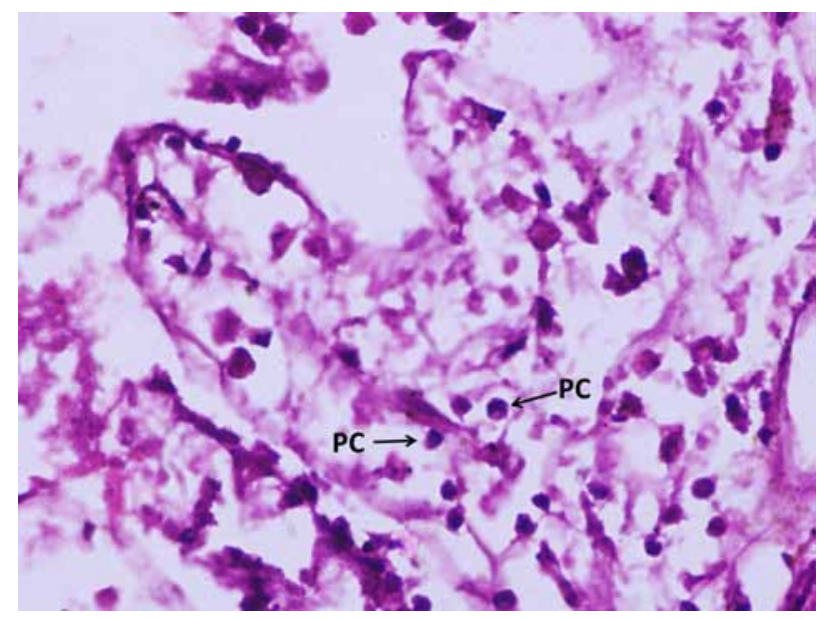

Figure 4. High power magnification (40x) of mucosa of the Meckel's diverticulum. Parietal cells (PC) can be seen clearly. 
Meckel's diverticulum is an incidental finding in most of the cases. It may be asymptomatic and may go unnoticed in many. However, it is capable of presenting many clinical complications. Many cases of volvulus and intestinal obstruction have been reported (KIM, CHA, LEE et al., 2008; ALTAF and AREF, 2014; BĂLĂLĂU, BACALBAŞA, MOTOFEI et al., 2015). Chances of intestinal obstructions increase when there are peritoneal bands or fibrous bands attaching the diverticulum to various other structures (MCANENY, RAPO and GRINDLINGER, 1989; KUNITSU, KOSHIDA, TANAKA et al., 2015). Intussusception is another complication as reported by many studies (ANWAR, AHMED, AL HINDI et al., 2014; LUBSZCZYK, KALISZEWSKI and STRUTYŃSKAKARPIŃSKA, 2015; HUNTINGFORD, MONTALTO and CHOUDHRY, 2015).

Meckel's diverticulum may get perforated by enterolith (GADHIA, RAJU and KAPOOR, 2013), foreign body (OKUR, ARSLAN, AYDOGDU et al., 2014), blunt abdominal trauma (EKWUNIFE, MBADUGHA and OGBUE, 2014) or when there is heterotrophic gastric or pancreatic tissue is present in it (AL-LAMI, ALAM, NAGY et al., 2013).

Meckel's diverticulum may be involved in several types of hernias. Cases of this diverticulum being involved in inguinal hernia (HORKOFF, SMYTH and HUNTER, 2014), obturator hernia (ARIF, ABIDEEN, ZIA et al., 2015), femoral hernia (MISIAK, PISKORZ, KUTWIN et al., 2014) and different types of internal hernias (FUENTES-DIAZ, TRUJILLOVASQUEZ, PARRA-VARGAS et al., 2015) have been reported.

\section{Conclusion}

Knowledge of morphology, pathology and symptoms caused by Meckel's diverticulum is of importance to gastroenterologists, surgeons, pathologists and radiologists. In most of the previous studies, giant Meckel's diverticula observed had some pathology. Our case is interesting because the size of diverticulum was not due to any pathology.

\section{References}

AKBULUT, S. and YAGMUR, Y. Giant Meckel's diverticulum: an exceptional cause of intestinal obstruction. World Journal of Gastrointestinal Surgery, 2014, vol. 6, n. 3, p. 47-50. http://dx.doi. org/10.4240/wjgs.v6.i3.47. PMid:24672650.

AL-LAMI, A., ALAM, M., NAGY, A. and KHAN, AR. A microscopically calcified Meckel's diverticulum: a histopathological perspective of a case of both gastric and pancreatic mucosae. BMJ Case Rep, 2013, vol. 2013 PMid:23440988.

ALTAF, A. and AREF, H. A case report: Cecal volvulus caused by Meckel's diverticulum. International Journal of Surgery Case Reports, 2014, vol. 5, n. 12, p. 1200-1202. http://dx.doi.org/10.1016/j. ijscr.2014.11.038. PMid:25460488.

AMIN, MU., SIDDIQUI, MK. and MAHMOOD, R. Inverted Meckel's diverticulum causing intussusception in an adult. Journal of the College of Physicians and Surgeons, 2008, vol. 18, n. 9, p. 574575. PMid:18803897.

ANWAR, MO., AHMED, HI., AL HINDI, S. and AL OMRAN, Y. Meckel's diverticulum with intussusception in a 5-year-old patient with Down's syndrome. BMJ Case Rep, 2014, vol. 2014 PMid:25540213.

ARIF, A., ABIDEEN, ZU., ZIA, N. and KHAN, MA. Perforated obturator Littr hernia in an elderly woman. Annals of Saudi Medicine, 2015, vol. 35, n. 4, p. 324-326. PMid:26497715.
BĂLĂLĂU, C., BACALBAŞA, N., MOTOFEI, I., POPA, F., VOICULESCU, S. and SCĂUNAŞU, RV. Meckel's diverticulum: a rare cause of intestinal obstruction in adults. Revista Medico-Chirurgicala a Societatii de Medici si Naturalisti Din Iasi, 2015, vol. 119, n. 1, p. 162-165. PMid:25970960.

CHEN, JJ., LEE, HC., YEUNG, CY., CHAN, WT., JIANG, CB., SHEU, JC. and WANG, NL. Meckel's Diverticulum: factors associated with clinical manifestations. ISR N Gastroenterology, 2014, vol. 2014, p. 390869. http://dx.doi.org/10.1155/2014/390869. PMid:25006469.

EKWUNIFE, CN., MBADUGHA, TN. and OGBUE, UN. Isolated Meckel's diverticulum perforation as a sequel to blunt abdominal trauma: a case report. Journal of Medical Case Reports, 2014, vol. 8, n. 1, p. 111. http://dx.doi.org/10.1186/1752-1947-8-111. PMid:24693872.

EMRE, A., AKBULUT, S., YILMAZ, M., KANLIOZ, M. and AYDIN, BE. Double Meckel's diverticulum presenting as acute appendicitis: a case report and literature review. The Journal of Emergency Medicine, 2013, vol. 44, n. 4, p. e32l-e324. http://dx.doi.org/10.1016/j. jemermed.2012.11.001. PMid:23340118.

FUENTES-DIAZ, JM., TRUJILLO-VASQUEZ, CA., PARRAVARGAS, AM., ROVIRA-CHAVES, AS., TINOCO-GUZMAN, LV. and GARCIA-GARCIA, JM. Strangulated internal hernia by giant Meckel diverticulum presented as acute appendicitis. International Journal of Surgery Case Reports, 2015, vol. 13, p. 61-63. http:// dx.doi.org/10.1016/j.ijscr.2015.06.010. PMid:26117448.

GADHIA, U., RAJU, D. and KAPOOR, R. Large enterolith in a meckels diverticulum causing perforation and bowel obstruction: an interesting case with review of literature. The Indian Journal of Surgery, 2013, vol. 75, n. S1, supplement 1, p. 177-179. http:// dx.doi.org/10.1007/s12262-012-0558-9. PMid:24426556.

HORKOFF, MJ., SMYTH, NG. and HUNTER, JM. A large incarcerated Meckel's diverticulum in an inguinal hernia. International Journal of Surgery Case Reports, 2014, vol. 5, n. 12, p. 899-901. http://dx.doi. org/10.1016/j.ijscr.2014.09.036. PMid:25460431.

HUNTINGFORD, K., MONTALTO, SA. and CHOUDHRY, MA. 3-year-old girl with Trisomy 18 and intussusception with Meckel's diverticulum. American Journal of Medical Genetics. Part A, 2015, vol. 167A, n. 9, p. 2226-2228. http://dx.doi.org/10.1002/ ajmg.a.37109. PMid:26108702.

ELSAYES, KM., MENIAS, CO., HARVIN, HJ. and FRANCIS, IR. Imaging manifestations of Meckel's diverticulum. AJR. American Journal of Roentgenology, 2007, vol. 189, n. 1, p. 81-88. http:// dx.doi.org/10.2214/AJR.06.1257. PMid:17579156.

KILIUS, A., SAMALAVICIUS, NE., DANYS, D., ZALDOKAS, G. and SEININ, D. Asymptomatic heterotopic pancreas in Meckel's diverticulum: a case report and review of the literature. Journal of Medical Case Reports, 2015, vol. 9, n. 1, p. 108. http://dx.doi. org/10.1186/s13256-015-0576-x. PMid:25956067.

KIM, EY., CHA, JM., LEE, JI., CHOE, JW., JOO, KR., JUNG, SW., SHIN, HP. and LEE, SH. A case of recurrent intestinal obstruction caused by Meckel's diverticulum. The Korean Journal of Gastroenterology, 2008, vol. 51, n. 6, p. 372-376. PMid:18604139.

KUNITSU, T., KOSHIDA, S., TANAKA, K., NAKAHARA, S., YANAGI, T., MARUO, Y., TAKEUCHI, Y. and KUBOTA, Y. Neonatal Meckel diverticulum: obstruction due to a short mesodiverticular band. Pediatrics International, 2015, vol. 57, n. 5, p. 1007-1009. http:// dx.doi.org/10.1111/ped.12694. PMid:26310428.

LAMBropoulos, V., PAPAGEORGIOU, I., KEPERTIS, C., SFOUNGARIS, D. and SPYRIDAKIS, I. Uncommon surgical causes of right lower quadrant pain in children: single center experience. Journal of Clinical and Diagnostic Research, 2015, vol. 9, n. 5, p. PR01-PR03. PMid:26155519. 
LUBSZCZYK, M., KALISZEWSKI, K. and STRUTYŃSKA-KARPIŃSKA, M. Unusual clinical picture of Meckel's diverticulum intussusception in 19-year-old man: a case report. Polski Merkuriusz Lekarski, 2015, vol. 38, n. 228, p. 332-334. PMid:26098653.

MCANENY, D., RAPO, SE. and GRINDLINGER, GA. Traumatic hemoperitoneum due to a Meckel's mesodiverticular band: case report. The Journal of Trauma, 1989, vol. 29, n. 2, p. 261-262. http:// dx.doi.org/10.1097/00005373-198902000-00024. PMid:2918569.

MECKEL, JF. Uber die divertikel am darmkanal. Arch die Physiologie, 1809 , vol. 9 , p. $421-453$.

MISIAK, P., PISKORZ, L., KUTWIN, L., JABŁOŃSKI, S., KORDIAK, J. and BROCKI, M. Strangulation of a Meckel's diverticulum in a femoral hernia (Littre's hernia). Przeglad Gastroenterologiczny, 2014, vol. 9, n. 3, p. 172-174. http://dx.doi.org/10.5114/pg.2014.43580. PMid:25097716.
OKUR, MH., ARSLAN, MS., AYDOGDU, B., UYGUN, I., GOYA, C., TOKGÖZ, O. and OTCU, S. Perforation of Meckel's diverticulum by foreign body. JPMA. The Journal of the Pakistan Medical Association, 2014, vol. 64, n. 7, p. 826-827. PMid:25255595.

SANCAR, S., DEMIRCI, H., SAYAN, A., ARIKAN, A. and CANDAR, A. Meckel's diverticulum: ten years' experience. Ulus Cerrahi Derg., 2015, vol. 31, n. 2, p. 65-67. PMid:26170751.

YAHCHOUCHY, EK., MARANO, AF., ETIENNE, JCF. and FINGERHUT, AL. Meckel's diverticulum. Journal of the American College of Surgeons, 2001, vol. 192, n. 5, p. 658-662. http://dx.doi. org/10.1016/S1072-7515(01)00817-1. PMid:11333103.

Received: December 22, 2015 Accepted: July 25, 2016 